\title{
The Fate of Eastern Europe Under "Marxism"
}

As interpreted by two world-famous leaders, Lenin and later Stalin, Marxism provided the ideological framework for the union of many nations. During the first thirty years of its development the USSR achieved one of the two leading positions of political power and prestige in the world. For four decades the Platonian dream of a government of philosophers has been a reality. It is not necessary to recall to the American reader the great achievements of Soviet Russia. On the ruins of the most backward despotism of the tsarist empire, the Russian Marxist party built a more modern empire, with the help of such great words as internationalism, equality, liberation, peace, and socialism. The blood of many generations of socialists fertilized the soil that underlay this achievement.

Some interested observers, however, are raising the question of the relation of this new empire, its ideology, and unquestionable achievements to the ideas of Karl Marx and to the socialist tradition. Any unprejudiced reader of Kołakowski's concise opinion about East European Marxism should understand that among many contemporary branches of Marxism the least Marxian was precisely the one used to build the Soviet empire and to introduce the new social system into eleven European states, independent before World War II.

The changes in the content of Marx's legacy that were brought about first by Lenin as a theorist, and second by Lenin and Stalin as politicians, and which have been sketched briefly by Kolakowski, ought to be somewhat enlarged upon if the reader is to comprehend the consequences of the introduction of Soviet Marxism to the northern, central, and eastern countries of Europe.

The difference between Marx's and Lenin's version of Marxism lies in their personalities. Marx was a West European philosopher who wanted to be a politician. Lenin was a politician, a "Russian from head to toe," who also wanted to be a philosopher, The two personalities of Marx, that of a politician and that of a philosopher, were in constant conflict with each other: the philosopher, whose main principle was de omnibus dubitandum (one should doubt all), usually dominated the politician. Lenin was more monolithic; he had no doubts when he adapted Marx's ideas to his task: to make revolution

1. The opinion of Grigorii Zinoviev-Radomyslski, Lenin's friend and long-time collaborator. See quotation in Wiktor Sukiennicki, Kolumbowy blqd: Szkice z historii, teorii $i$ praktyki sozerieckiego komunizmu (Paris: Instytut Literacki, 1959), p. 35. 
in a country where the "Asiatic mode of production" had survived into the twentieth century. In his purely philosophical statement he followed Engels rather than Marx. (It should also be emphasized that Stanisław Brzozowski and later Bertrand Russell were right in stating that Engels never understood the essence of Marx's materialism.)

The distortion of classical Marxism occurred in two stages. The first stage began with the victory of the proletarian revolution in the most backward of European empires. The second coincided with the spreading of Soviet Marxism to European countries of non-Russian history and culture.

The political genius of Lenin led him to strengthen the voluntaristic element in Marx's theory of social change, and to reduce the rest of Marx's thought to the ideology of militant communism. Lenin's concept of the party as a conspiratorial organization of "professional revolutionists" (presented in his famous pamphlet What Is To Be Done? in 1908) not only differed from Marx's concept of the party as a democratic mass organization but exerted an essential influence on later interpretations of Marxism. We must remember that one of the principles of Marx's philosophy was the unity of theory and practice.

After the Bolshevik Revolution, "Marxism-Leninism" became an ideology of a dictatorship which joined the elements of a German philosophy of the state (Hegel's "Objective Spirit") with the tradition of the oldest police state in Europe, built in the sixteenth century by Ivan the Terrible's Oprichnina and the climate of the Russian mysticism of power that originated in the Byzantine Empire. The task of further reducing Marxian thought to the status of a tool for the building of this state, which became fashionable enough to bewitch Western intellectuals for a half century, was performed by Joseph Stalin. Within the party he not only needed to liquidate the old core $(600,000$ persons) and send three times as many to concentration camps, but he also had to kill communism as a social movement. It was impossible to permit the people of the Soviet countries to develop Marxist philosophy, which-right or wrong-is in its very essence a philosophy of permanent change. The idea of class hatred, the motivating force that vitalized the whole of Marx's philosophy, facilitated the purges organized by Stalin.

Contemporary Marxists try to place all the blame for the inhuman aspects of the Marxist states, for all the internal and international crises of the Soviet empire, for the humiliation and death of uncounted millions of innocent people, and for the destruction of cultural life on Stalin.

This is a simplification. These contemporary Marxists try to forget that Stalin only went further along the path on which Lenin had guided the revolution. Lenin prepared the ideological framework of Communist totalitarianism and is rightly called "the architect of twentieth-century totalitarian- 
ism."2 There were, of course, great differences between these two men. Lenin was first of all a well-educated student (he received a gold medal in high school and a gold medal with a first class honors degree from St. Petersburg University) and a well-bred Russian gentleman who devoted his life, thought, and emotions to the liberation of the world proletariat. A desire for power, if present at all, does not seem to have been a chief motive of his actions. In these respects Stalin was his polar opposite. A Tiflis shoemaker's son, Stalin had an incomparably lower education and individual abilities. His primitive as well as unlimited desire for power would never have given him the position of an absolute ruler of the party had it not been for the changes that Lenin introduced into the Marxist movement. When opposing the majority of other revolutionary leaders of the left, Lenin tried to change the political party into a centralistic organization based upon military patterns of subordination and on secrecy and complete Machiavellian morality. On the other hand, there is some evidence that he truly believed that this kind of party and these kinds of methods were needed only to secure and accelerate the victory of the proletariat. The "dictatorship of the proletariat" as well as the state itself, he believed, would gradually disappear after a rather short period of revolutionary terror. Stalin rejected Lenin's noble dream concerning the undefined future, but he developed Lenin's concrete plans to their final logical conclusion.

It was for this reason that the party became a strong organization of Communists who became captivated by the bureaucratic apparatus. Once Stalin took the highest post of general secretary, he was slowly able to achieve absolute domination over the party and the state. Lenin warned against Stalin because of his brutal character, but he did not foresee where the ship he had built wottld sail. ${ }^{3}$ It was Lenin's "Columbus's mistake" that the promised land to which he led his people turned out to be completely different from the one that was planned by Marx, Engels, and himself. ${ }^{4}$

In order to change the nineteenth-century ideology of liberation into an instrument of mass brainwashing totalitarianism and a new form of imperialism, Stalin had to take further steps in the castration of Marxism, changing it into the dead form of an all-resolving formula. Many millions of people had to die to make his simplified Marxism workable.

At the same time that European civilization had become more secularized

2. Bertram D. Wolfe, An Ideology in Pozver: Reflections on the Russian Rcvolution (New York, 1969), p. 164.

3. All attempts to point out the not really serious personal conflicts (which took place toward the end of Lenin's life) between these two creators of Soviet Marxism as evidence of deep political differences between them are childish efforts at covering the historical reality.

4. Columbus's Mistake is the title of the book cited in note 1, by Professor Sukiennicki, a Polish leftist living in exile, who is one of the greatest experts on Soviet history. 
than ever before, Soviet Marxism laid the foundations for a modern sacred state. Its construction and preservation was Stalin's highest achievement.

Before the "October Revolution" the Russian intelligentsia, the only Westernized social force in the country, worked to secularize the "New Byzantium" (as the tsars proudly called the Moscow empire). It was the achievement of the intelligentsia that the work of Marx became popular among the people of the left. However, the mentality, the anarchistic inclinations, the fascination with Western culture, the critical ability, and finally the social manners of this stratum did not fit the ethos of the masses and their professional leaders. This intelligentsia had to be thrust aside before the "objective laws of history." The party, which is always obedient to these "laws," treated the intelligentsia as a part of the bourgeoisie and condemned both to liquidation. The orthodox seminarian Joseph Vissarionovich Dzhugashvili Stalin was a typical example of the half-educated people who in Russia never enjoyed the status of members of the intelligentsia but who made careers in the Bolshevik party. Survivors of the stratum (called "nedorezanii") did not reconstruct this social stratum in the postrevolutionary time. Some dispersed groups of the old intelligentsia survived: this was especially true of physicians and of experts and high-ranking specialists in industry and in the natural and technological sciences. Of course, these persons ceased to be members of a united, spiritually independent stratum. They became powerless members of the new highly stratified middle class, which in Communist countries received the name "working intelligentsia."

In a culturally backward society without a relatively unified stratum of educated people who can keep in contact with the current achievements of advanced countries and exercise some influence on political life, the process of "sacralizing" power and the fundamental institutions of the new society proceeded very fast. Like the tsar, who united and embodied all political and religious power, Stalin became an absolute authority in all fields. The Communist Party changed from a militant organization into a bureaucratic but "fighting church." The epoch of the "New Middle Ages" began. The domination of the sacred collective over the secular individual, the restriction and control of all social activity and any new initiative, and finally the brainwashing interference of the secret police even with the private sphere of life, created the unbearable atmosphere of the state which pretended to call itself "socialistic."

5. The new regime organized mass education with special courses called rabochye fakul'tety for those upwardly mobile people who were appointed to take the leading positions in civil administration, the judiciary, education, and industry.

6. A young American sociologist, Mr. D. Roth, called my attention to the interesting fact that in the American sociological vocabulary, as well as in Webster's Dictionary, the term for a process opposite to "secularization" does not exist. 
The relatively small group of professional revolutionaries consolidated its position for good. The immutable nature of this ruling caste became another of the "feeudal" characteristics of this new society. In Soviet life, as in all the utopias that have been written of in the past, "religious" factors began to play an important role. The Soviet canon of Marxism ceased to be a subject of critical study and became a dogmatic truth taught rigorously and in a way reminiscent of religious rituals. The great task of indoctrinating the millions of uneducated people could be accomplished only by means of the most primitive "mass media," such as ceremonies, the repetition of slogans, rhetorical speeches, mass meetings, marches for creating a crowd hypnosis, and the like.

All these well-known characteristics of the Soviet state must be kept in mind if we try to understand the impact of Soviet Marxism on the cultural development of that part of Europe which had not in the past experienced tsarist despotism, the Orthodox Church, and three hundred years of domination by the Golden Horde, and did not have a large proportion of Asiatic population.

The "national character" is not an operational, empirical, or measurable category in sociology. Nonetheless, in observing social processes over a long span of time, we must recognize its meaning. Soviet Marxism became a "Russian" issue. ${ }^{7}$ Traditional Russian attitudes impregnated the official ideology of the first Marxian state. The main characteristics of this state that are related to the Russian past are (1) political absolutism, expressed by rejecting democratic separation of powers as well as by the unification of ideological (religious) and political authority in the same hands; (2) the "semihereditary" character of the ruling caste, which by definition cannot be replaced by another political group; (3) the ruler's contempt for the opinion of the masses, deeply rooted in anti-individualistic attitudes; (4) terror of the secret police as the chief instrument of governing; and (5) sacralization of power.

With the exception of Czechoslovakia, where the Communist Party was large and influential, Soviet Marxism arrived in the East Central European countries in the baggage train of the Red Army after 1945. Since this date it has had to face its greatest danger: a confrontation with Western philosophical

7. One of the reasons the concept of "national character" awakens a feeling of repulsion in liberal sociologists is their materialistic and anthropological concept of nation. In fact, however, nation is a spiritual phenomenon, a product of history and common experiences, but not of a race. The results of the Marxist Revolution in Russia were at the very beginning predicted by some intelligent observers on the basis of national characteristics. One of the greatest twentieth-century Polish poets, Julian Tuwin, a party member, predicted what is known today as the period of the "cult of personality" (in his poem "Wielká Teodora," which is not well known because it was never re-edited after 1945). 
traditions, with Western Christianity, and with the deeply rooted tradition of political institutions based on the Roman law. ${ }^{8}$

The confrontation was shocking for both sides. A lack of understanding of these deep differences in cultural traditions caused many tactical mistakes in the process of introducing the new philosophy as well as in that of political subjugation. The cultural gap that separated tsarist Russia from the rest of Europe was deepened during the first twenty-eight years of the building of "socialism" by the policy of rigorous isolationism (1917-45).

Soviet "advisers" and the secret police viewed these countries through glasses colored by information derived from the sacred books of Marx and Engels, although these works were written in the nineteenth century. Meanwhile, a new set of European nations established their independence (Yugoslavia, Hungary, Czechoslovakia, Poland, Lithuania, Latvia, and Estonia). With the exception of Czechoslovakia, each had a bourgeoisie that was not strong industrially or financially. The countries that the Western powers abandoned to the Soviets in 1944-45 were strongly differentiated both by their political development in the period between wars and by their fate during the war. Czechoslovakia, the most democratic among them, survived World War II without great losses of population or devastation of its countryside. Hungary and Rumania became Hitler's satellites but did not profit by it. Of these countries, the one with the largest population and territory, Poland, suffered during the war the most cruel devastation and multiple decimations of her population. In all the countries occupied by Hitler's armies, the longing for democratic changes was deepened. In Poland the resistance movement brought about a process of political and social change leading toward a kind of people's democracy completely independent of, and essentially different from, the Communist model of "people's democracies." The political parties of the Polish Underground State (the greatest phenomenon of this kind, the history of which is still veiled by Communist propaganda) issued and accepted a program of social reform whose main items were the same as the later program of the Kremlin agency for Poland-nationalization of industry, complete agricultural reform, democratization of political institutions, and the improvement of relations with national minorities. In these circumstances, a Communist government of Poland, in order to pave the way for the new ideology, had first of all to spread incriminating calumnies about the Second Polish Republic (1918-39) and the underground state. Originally the task of indoctrination was very difficult because the Polish Communist Party, which never was a

8. In describing the situation of these countries since 1945, I consciously omit the purely political problems, such as the physical liquidation by arrest, execution, and deportation of the people of the anti-Nazi underground movement in Poland (1944-48), the destruction of all non-Communist parties in other countries, and the changing by force of all traditional institutions, organizations, and forms of political life. 
strong social force, was decimated by Stalin, who invited actual and potential leaders of other parties to Moscow and liquidated most of them during the Great Purge of 1936 to 1939.

In Czechoslovakia the introduction of the new "faith" was facilitated not only by the existing, stronger Communist Party but also by the traditional friendship between these two nations, which had never had conflicting interests in the past. Rumania and Hungary were treated as fascistic territories, where the new order had to be introduced without any discussion. Yugoslavia was the only country that experienced a real social revolution during the war and produced its own original communism.

The tragedy of the Baltic countries devoured by the Big Brother is not known in sufficient detail. Thus I cannot discuss the conflict of the Old with the New in those territories.

In East Central Europe (Rumania, Hungary, Czechoslovakia, and Poland), despite the different circumstances of the past and the war, mentioned above, the patterns of Soviet Marxist indoctrination were rather similar. Contrary to the prevailing views, the ideological struggle in all these countries was not limited to the conflict of the new ideology with traditional democracy, liberalism, nationalism, or even fascism. We witnessed above all a conflict of civilizations, a conflict of attitudes deeply rooted in the mentalities of the adversaries, attitudes toward life and death, toward the relationship between the individual and the state, toward philosophy and religion, and attitudes concerning politics, morality, and aesthetics.

It should be recalled that (at least during the nineteenth century) all these countries experienced longer or shorter periods of subjugation and oppression by foreign powers. These common experiences are one of the basic reasons for the individualism that manifested itself in various forms in a continuum ranging from the Polish or Hungarian "insurgent" to the Czech "Soldier Szwejk."

The critical, suspicious, or at least skeptical attitude, traditional among these nations, toward all governmental issues played a significant role in the adaptation of Marxism. The overwhelming majority of their populations treated Soviet Marxism as a religion imposed by the new "occupants" (directly replacing the Nazis). The Communist governments organized systematic indoctrination in Marxism-Leninism for all generations. The new subject was most seriously taught in all institutions of high and higher education. (Grammar-school children were introduced into the new faith by means appropriate to their ages: songs, poems, and moving anecdotes about the "sun of our life," Generalissimo Stalin.) Also, in all offices of state administration and related institutions, people of the older generation were compelled to participate in seminars on Marxism-Leninism. Only administrative terror kept the millions of overtired and disinterested people in these classrooms. The results obtained 
were exactly the opposite of those desired. The self-defense system of the subjugated peoples produced thousands of jokes on the subject as a new religion which has many practitioners but few believers.

In the academic sphere the fate of Marxism was no better. Among the generation that started its academic life just before World War II, the few Marxists who survived German persecutions fell into two groups, those who revolted against the Soviet edition of their philosophy and those who, being more opportunistic, decided to take their chances with it. The new school of thought and life found the largest number of followers among the generation that was indoctrinated in the high schools of the "new era." The great intellectual battle raged in all the universities from 1945 to 1949. The battle finished with the administrative victory of the newly appointed professors (most of them without serious academic qualifications) and of a few "betrayers." After 1949 the new universities began producing the young Marxist generation. So-called janissaries of socialism were being trained in "Higher Party Schools." However, neither culture nor science can be built by one generation. The new Marxist countries had their own intellectual tradition, which survived despite all damage. The influence of the Vienna Circle and of the Polish school of analytical philosophy ${ }^{9}$ undermined the gigantic efforts of Communist parties to erect one monolithic Weltanschaunng. The conflict of opposite trends and ideas, as we know from the whole history of social and philosophical thought, is always very fruitful.

At the beginning it seemed impossible to exercise any influence on the people who accepted the content of certain "classical" texts as a truth that was above all discussion. Even for those who wanted to discuss the sacred truth of their Scripture, polemics were very difficult because their philosophical language was entirely different from the language of Western philosophy. Despite these circumstances, the influence of older, non-Marxist philosophers on young Marxists was tremendous. Without non-Marxist teachers, such as Kotarbiński and Ajdukiewicz-Kolakowski is unimaginable. ${ }^{10}$ Many outstanding people of the younger generation, as well as older scholars, escaped to the harbor of historical studies to avoid the hopeless confrontation with the omnipotent Marxists, who began their offensive approximately in 1950.

The tactics of this attack, proved on Russian soil, failed on the banks of the Vistula, the Moldau, and the Danube. A vulgar interpretation of Marxism, a complete neglect of "fair play" in discussion with representatives of other philosophical schools, and-above all-the abuse of traditional terminology as a method of intellectual campaign, united the opposition in these countries. 1967).

9. See Hẹnryk Skolimowski, Polish Analytical Philosophy (London and New York,

10. See Henryk Skolimowski, Polish Marxism (New York: Columbia University Press, in press) or in Polish, Polski Marksizm (London, 1969). 
Soviet Marxism became a target of poisonous jokes, which would appeal even to the youngest. The philosophy of "Diamat" (as the new prophets called dialectical materialism) faced well-trained and analytically minded scholars who could be defeated only by administrative means. All of these scholars lost their chairs in the late forties and early fifties. Nonetheless, their quiet defense of non-Marxist positions compelled the Marxists to think about the deficiencies of their own philosophy.

The battle between Marxists and the philosophers of all other schools (labeled "bourgeois") was probably most interesting in Poland, where a rather large number of philosophers, logicians, and mathematicians had won a world reputation before World War II.11 In that country the attacks of Soviet Marxism were condemned to fall flat. As an ideology it met a rapid renewal of Catholicism. As a philosophy it faced a living tradition and a strong, though quiet, and sometimes masked, defense of the positions of analytical philosophy, phenomenology, personalism, and Thomism. Naturally enough, official reports proclaimed the great victory of the official philosophy. This seemed to be the case for a while. All chairs were in Marxist hands; nonMarxists could neither teach nor publish; the youth was organized and systematically indoctrinated. All these facts notwithstanding, the Marxists gained only a Pyrrhic victory. The generation of great Polish philosophers could not openly rear their successors, but, oddly enough, that interesting phenomenon rightly named "Polish Marxism" must to a large extent be credited to them. They "educated" a generation of younger philosophers who were able to transcend the limitations of Marxism, and not only of Soviet Marxism, to be what are called by their party enemies "revisionists." Not all of them were able to see the "fate of Marxism" as Kolakowski did; not all of them were willing to express their real views, but even among those who stayed in the country after the purge of 1968 , the only Marxists who were able eventually to exercise any influence on public opinion and the youth were those branded with the stamp of revisionism. We can thus say that the battle for the "government of souls" in Eastern Europe was lost for the Communists. (The Western reader should remember that the people with twenty-five years of experience in the Soviet bloc sharply differentiate between socialism as an economic system and communism as a totalitarian ideology.)

Originally the intellectual offensive of the Communists was more successful in economics. A planned economy required immediate answers to many new problems. Each attempt to introduce or to use tested methods of "bour-

11. Philosophers: Kazimierz Twardowski, Kazimierz Ajdukiewicz, Tadeusz Kotarbiński, Władysław Tatarkiewicz. Logicians: Jan Lukasiewicz, Stanisław Leśniewski, Leon Chwistek. Mathematicians: Wacław Sierpiński, Stefan Banash, Casimir Kuratowski, Hugo Steinhaus, Stanisław Saks, Alfred Tarski (also a logician), Stanislaw Zaremba, Stefan Mazurkiewicz, Karol Borsuk, Antoni Zygmund, Marek Kac, Stanisław Ulam. 
geois" economics was treated almost as treason. The older economists were dismissed as people unable to adapt their minds to the new "philosophical economy." Some of them who were Marxists but did not want to put their hands on the assembly line of the new ideology escaped to historical studies. This was true of one of the grand old men of Polish socialism, Professor Edward Lipinski, whose famous saying addressed to the Communists was "Do not believe that socialism is so far removed from the common sense as you appear to think!" But his was a voice in the desert until 1956. At the end of the 1950s the most significant innovation to the traditional interpretation of Marxist economic doctrine was introduced by Oskar Lange, who, wishing to make a political career, pretended to be faithfully orthodox. Nonetheless, his work is a serious attempt to combine Marxian premises with the methods and tools of modern economic thought. His contribution to econometrics and cybernetics introduced scientific inquiry into the environment of younger Marxist economists.

Next to economics, sociology was a field in which views other than Marxist could not be tolerated after 1950. Not a single chair of sociology has existed in the Soviet Union for the last three decades. Sociology was simply replaced by Marxism-Leninism. The fate of sociology is an interesting example of the social consequences of a false interpretation of Marx's thoughts and polemics. Marx rejected the ideological aspect of Comte's concept of sociology as well as his concept of objectivity, which, according to Comte, was achievable by adapting methods of the natural sciences to sociology. But on the basis of different principles, Marx himself introduced numerous sociological ideas. Half of his own research is of a sociological nature. Soviet Marxists, however, threw the baby out with the bath water. For them, the term "sociology" was too closely associated with bourgeois investigators of social phenomena. All sociologists, from Comte through Durkheim to contemporaries, were condemned. Developed methods of modern sociology were thrown away. For more than thirty years the development of sociology did not exist for the Soviets. Therefore the gap in intellectual development between Soviet Russia and Eastern Europe was greatest in this field.

At the very beginning of the fifties, departments of sociology as well as of philosophy were abolished in all the satellite countries. They were replaced by departments or centers of "social sciences," within which philosophy was replaced by dialectical materialism and sociology by historical materialism. The process of vulgarization sometimes took an amusing form. A new "greatest authority" appeared in Marxist publications: his name was Mels. (A seminar discussion between the outstanding Polish professor of sociology Stanisław Ossowski and one of his Marxist Ph.D. candidates became a famous anecdote of the period. The young man argued using quotations from Mels. They sounded familiar to the professor, who was very well educated in the 
heterogeneous Marxism of the Western Left, but he became somewhat confused and noted that some of those thoughts were interesting but that he had never heard the name of this author. The astonished young man replied: "How is this possible? It is just Marx, Engels, Lenin, Stalin, or MELS.")

In sociology as well as in philosophy the intellectual background of the conquered countries appeared to be stronger than the demands of the new ideology. In all these countries there were many sociologists who were very familiar with Marxism, and even those who never declared themselves as Marxists accepted or used some Marxian ideas. These people could defend their intellectual independence in two ways: they either twisted the titles of their publications and paid false homage in a more or less opportunistic way to the "immortal" thoughts of Mels, or they openly confronted orthodox Marxism with their heterodox brand. The answer of the Marxists in power to the latter was very simple: they closed their mouths with administrative orders.

How are we to explain that despite all the efforts of Soviet Marxists, the younger generation of sociologists, and even those who during World War II were educated in Soviet institutions, threw away the burden of orthodox indoctrination with the first green lights, two years after Stalin's death? The moral attitude of the older generation of scholars, who had the courage to defend their views against all the attacks of the Communist authorities, was of great importance in this respect. (In Polish sociology this role was played during the whole postwar period by an outstanding couple, Professors Stanisław and Maria Ossowski. He died in 1963, and she is still a living symbol of moral and political nonconformity.)

The brief period of liberalization saved intellectual life. Polish sociology boomed, and philosophy broke out of the dialectical walls. In 1957 a young Warsaw sociologist, Andrzej Malewski, made a heavy attack on historical materialism-Marxist sociology. He questioned the empirical validity of this sociology. ${ }^{12} \mathrm{He}$ stated that historical materialism consists of three sets of hypotheses that concern (1) patterns of behavior and beliefs of people pertaining to the life situation, (2) society as a system of socioeconomic classes with conflicting interests, and (3) a particular theory of social change.

In the best manner of the analytical school, Malewski proved that some of the Marxian theories dealing with the regularities mentioned above were statistical or causal in character. Theories of the second group are even more difficult to reformulate in empirical forms than the first. Malewski pointed out that Marx's theory of social change had only a limited use-as a particular, not a general, theory of change.

12. Andrzej Malewski, "Empiryczny Sens teorii materializmu historycznego," Studia filozoficzne, 1957, no. 2, pp. 58-81. 
It was the first time in the Soviet bloc that such an open criticism of the "Scripture" was published. The young critic described historical materialism as ideological statements without empirical meaning, mixed with false surmises, though with some deep intellectual insights. ${ }^{13}$

All that happened in Polish philosophy is well known to foreign readers owing to the translation of some of Kolakowski's books. Marx's dialectical conception of social development gained a new great proof in the fact that from the conflict of the old "thesis" (analytical philosophy) with the new "antithesis" (Marxist philosophy), a new "synthesis" had appeared. Whether the "young philosophers" should still be called "Marxists" or not is a matter for a separate discussion. (The significance of this synthesis for the future world development is yet underestimated. Its creators do not seem to comprehend the role that history has imposed on them.)

We can say that the whole cultural tradition of the educated strata of the East European countries was the real foundation that made it possible for independent thought to be defended in Poland, Czechoslovakia, and Hungary. Even upwardly mobile people of the lower classes, who had not participated earlier in national high culture, now gained education in the new philosophy and mixed it with all the cultural elements of their countries' traditions.

Once more, as on many other occasions in the rich history of Europe, the culture of invaded countries defeated the ideology of invaders. In a sense, Eastern Europe became the graveyard of Soviet Marxism. But the cost of this twenty-five year struggle was tremendous.

Since it is impossible in a short sketch to review the damage to all aspects of the social and cultural life of the East European countries that occurred during the Soviet-Marxist ideological campaign, we should glance at least once at the more important ones. These are (1) social ties and (2) morality.

The ideologists of the totalitarian dictatorship realized that in order to build a "socialist" society all kinds of social ties must be destroyed. I am inclined to assume that there were some intellectuals who believed it was necessary for the old ties of their societies to be totally destroyed so that the way for the New might be opened. But politicians (let us remember again, Marxist policy and ideology are inseparable, and each politician pretends to be an ideologist) remembered very well that "the scientific concept of dictatorship means neither more nor less than unlimited power, resting on force, not limited by anything, not restricted by laws, nor any absolute rules" (Lenin). This modern type of dictatorship demands the elimination of all social units and ties. Family, religion, historical tradition, or independent associations could interfere with the unlimited will of state authority. The process, which quickly

13. An excellent presentation of Malewski's criticism is given in Z. A. Jordan, Philosophy and Ideology: The Development of Philosophy and Marxism-Leninism in Poland Since the Second World War (Dordrecht, 1963), pp. 460-63. 
acquired a popular label, "the dunging of the nation," was well organized. The education of youth played the fundamental role: the younger generation grew up in an atmosphere of a double morality provided by the home and the school. Workers lived in double consciousness: the mirage of sharing in the dictatorship of the proletariat, and the compulsion to cheat or constantly steal state property in order to maintain their families. Peasants survived in intermittent fear of collectivization; the intelligentsia stopped playing their social role of upholders of national values and independent producers of cultural goods, and were reduced to the role of obedient servants of the state. Nations as historical units were deprived of their history. The young generation of East European countries received historical textbooks of their history, sometimes written in Moscow or basically "corrected" by new historians of the regime. Serious historians had to escape to the safety of narrow, meaningless problems or had to fight for each page, each line of their works. But even in this field more outstanding personalities did not surrender. The struggle continues.

Nineteenth-century Marxists and most of the intellectuals of the West believed that communism would erase nationalisms. More sophisticated observers understood (especially after the Russian Revolution) that this would not occur. ${ }^{14}$ The rapid upward mobility, and the fictitious but influential slogans about the authority of workers and peasants, stimulated national aspirations and ambitions. The imperialistic policy of Soviet Russia helped to increase "defense nationalism" among subjugated peoples. Today it is obvious that nationalism became the most dramatic centrifugal force of the Soviet bloc. The voice of nationalism appears in different forms in almost all satellite countries and among the various Soviet nations. The expulsion of citizens of Jewish origin from Poland in 1968 is only one sorrowful episode in the increasing wave of nationalism awakened by Soviet Marxism in practice. Nationalism is one of the most powerful forms of the reconstruction of social integration on the lowest level of cultural life. In Eastern Europe it has been a symptomatic reaction against the disintegrative policy of the Soviet totalitarianism. At the same time it is a new step in the moral regression of the part of the world under Soviet Marxism.

The universal morality, which in European civilization was spread by the Jewish sect of Jesus Christ's followers, dominated-despite all abuses-the civilized world for nineteen centuries. The regression came from two sources politically opposite, but equal at least in choosing the means for the goal's realization. The tribal morality of racism (the basis of all nationalism) as well as the class morality of Marxism represent the same tragic rejection of the universal morality of Christianity and other great universal moral systems.

14. See Herbert Luthy, "La France seule," Preuves, May 1954. 
As a matter of fact, we should be rather astonished that the contemporary explosion of nationalism in the Soviet bloc was not predicted by social scientists, and today surprises intellectuals. It is not a mystery of the dialectics of history but simply a link in the chain of causes and effects brought about by revolutionary upheavals and an ideology that has used hatred as a political instrument.

Marxist elites fighting for the liberation of the masses took into account neither Pareto's "circulation of elites" theory nor their own principles of dialectics. They consolidated their own lifelong positions, since they were convinced that one generation would be enough to change the "gears of history." They believed that those who would come after would be indoctrinated completely and their own class-consciousness would be meaningless.

In the countries of imported communism the new step in the emancipation of the masses was complicated by the encroachment of national feelings, even of those classes which had become equal partners in political life only since the end of the nineteenth century. The "liberation army" of invaders brought to the consciousness of the masses (above all, the peasants) the feeling of a new threat. In the countries in which internal policy was dominated by narrow groups of Communist intellectuals and pseudo-intellectuals, the rapidly liberated masses demanded the promised paradise according to their own taste and standards. The slow development of a new type of nationalism in Eastern Europe took place two decades before its manifestations in the events of the late 1960s. The conflict of Communist "liberals" with Communist "nationalists" is, in fact, a conflict of the party intellectualism with the myth of a "true" people's power. Ideological battles are no longer really important. The new national Communists are fighting against Marxist revisionists, but under the veil of old dogmas they are seeking to organize a "Reformation" of the old universal "church" of Communism. They are replacing it with national "churches." And once again in European history, the "Holy Inquisition" (that of the Stalinist period) has been abolished to make a place for nationalistic wars and persecutions.

At the end of this very general description of the depressing aspects of the East European situation, I have to record one optimistic observation. Despite all Soviet Marxist indoctrination, interpersonal as well as interclass relations are slowly changing. Limitation of the impersonal power of money positively affects certain fields of human relations; that fact is recognized even by the most anti-Communist minded members of these societies. 